\title{
Lorenz Nissen
}

\section{Dansk præst i Flensborg 1796-1801}

\section{af Johann Runge}

Bondesønnen Lorenz Nissen fra Østerby (Kar herred) er vel en af de mest interessante danske præsteskikkelser i Flensborg i ældre tid. Bibliotekslektor Johann Runge tegner her et portræt af den selvlærte præst - og kaster samtidig et nuanceret lys over det danskes position i den store handelsby sidst i 1700-årene.

Sandsynligvis har der fra reformationens tidligste dage været holdt danske gudstjenester i Flensborg, snart i den ene, snart i den anden af byens store kirker og vel først og fremmest på kirkens højtidsdage.

Men i 1588 eller mere sandsynligt lidt før anså rådmændene og de deputerede borgere det for nødvendigt at indrette faste danske gudstjenester i byen, og det blev bestemt, at disse skulle afholdes i den lille Helligåndskirke på Flensborgs Storegade. I august 1588 ansattes en fast dansk prædikant. Han skulle holde danske prædikener og tage folk til skrifte. De egentlige kirkelige handlinger dåb, vielse og begravelse, samt efter 1646 konfirmation - blev derimod fortsat foretaget af byens tyske sognepræster i deres respektive kirker - og på (neder)tysk. De danske kirkegængere blev ikke løst fra deres tyske sognebånd. Disse forhold fortæller os en del om både menighedens og præstens kår: Helligåndskirken fik ikke status som sognekirke, og præsten ved denne kirke var kun en prædikant, som indtog det nederste sociale og økonomiske rangtrin blandt byens præster. Menigheden ansås for at være en sprogmenighed med skiftende medlemmer, først og fremmest beregnet til folk, der var flyttet til byen nordfra. Det tyske sprog var Luthers sprog, og dermed var tysk sprog og tysk gudstjeneste sandheden nærmere end dansk sprog og dansk gudstjeneste. Så snart de danske kirkegængere havde lært så meget tysk, at de kunne følge en tysk prædiken, forventedes det af dem, at de deltog i deres sognekirkers tyske gudstjeneste.

Efter kirkeordinansens ordlyd havde menighederne ret til at deltage i præstevalg. Men de danske kirkegængere dannede ikke nogen sognemenighed, og dermed faldt valg af deres præst uden for normen. Valget af den danske prædikant var et verdsligt anliggende. Byens to borgmestre, rådet og de deputerede borgere opslog embedet, inviterede kandidaterne til prøveprædiken, valgte og ansatte prædikanten. Valget foregik på rådhuset.

De danske kirkegængere boede spredt over hele byen, selv om meget taler 
for, at langt de fleste havde bopæl i byens nordlige områder, i St. Marie sogn og Ramsherred og $\mathrm{i}$ bydelen, som grænsede mod det dengang endnu dansktalende Angel, d.v.s. Hulvejene (i dag Glücksburger- og Kappelner Straße). Men der fandtes mange flere Flensborgere, der ønskede dansk gudstjeneste, end byens råd havde regnet med, da det indrettede den danske gudstjeneste i Helligåndskirken. I 1590 indførtes der nemlig danske middagsgudstjenester, der hver anden søndag afholdtes $i$ en af byens to store tyske sognekirker, desuden var der dansk gudstjeneste i Helligåndskirken hver mandag. Og det har næppe kun været underklassen, der besøgte de danske søndagsgudstjenester. Denne gudstjenesteordning varede til 1660'erne. Fra og med marts 1668 holdtes de danske søndagsgudstjenester igen kun i Helligåndskirken. Dansk var omkring 1600 absolut ikke et fremmedsprog $\mathrm{i}$ byen Flensborg. Men $\mathrm{i}$ anden halvdel af 1600-tallet gik deltagelsen i de danske gudstjenester stærkt tilbage. Hvordan var forholdene omkring 1800 ?

\section{En prøveprædiken år 1795}

Simon Bladt, nr. 12 i den danske præsterække siden 1588, døde i begyndelsen af januar 1795. Magistraten forhastede sig ikke, da det danske prædikantembede skulle besættes igen. Først på anden søndag i advent $(6 . \mathrm{dec})$ samme år holdt ni kandidater deres gæste- eller prøveprædiken i Helligåndskirken. De tre af kandidaterne inviteredes til at holde "valgprædiken« den 16. marts 1796, onsdagen før palmesøndagen.

Helligåndskirken var stuvende fuld, da de tre konkurrerende kandidater holdt deres prædikener. Det var rektor Johann Nicolaus Reuter fra Egernførde, ${ }^{1}$ cand. theol. Thomas Hoyer Jensen fra Tonder ${ }^{2}$ og den daværende skriveog regnemester i Sønderborg og nybagte cand. theol. Lorenz Nissen fra Østerby (Medelby sogn), der hin onsdag før palmarum 1796 kappedes om det danske prædikantembede i Flensborg. ${ }^{3}$

De holdt deres valgprædiken på dansk - noget der var langtfra givet, hvad et blik på Flensborgs nordlige naboby Aabenraa viser. Her skulle der i 1782 vælges en ny diakon, til hvis embedspligter den danske froprædiken hørte. Provst Ludolf C. Bargum foreslog sammen med amtmanden, at den nye diakon skulle holde valgprædiken på dansk. Det afslog byens deputerede borgere kategorisk, idet de påstod, at det tyske sprog var hovedsproget for diakonen, og for de vælgende menighedsmedlemmer det sprog, de forstod. At diakonen skulle holde dansk froprædiken betød efter deres mening intet, da den var indrettet for de ikke-tyskkyndige tjenestefolk, der ikke havde valgret. ${ }^{4}$ En besynderlig argumentation! Magistrat og deputerede borgere i Flensborg 
Under billedet af pastor Lorenz Nissen (1754-1842) er tilfojet hans motto - på tysk: "Der Mensch kann, was er ernstlich will, wenn es nur an sich nicht unmöglich ist". Efter denne fornuftspragede livsregel arbejdede den sonderjyske bondeson sig ad omveje frem til en anset stilling som prast. Gengivet efter selvbiografien fra 1826, genudgivet 1982.

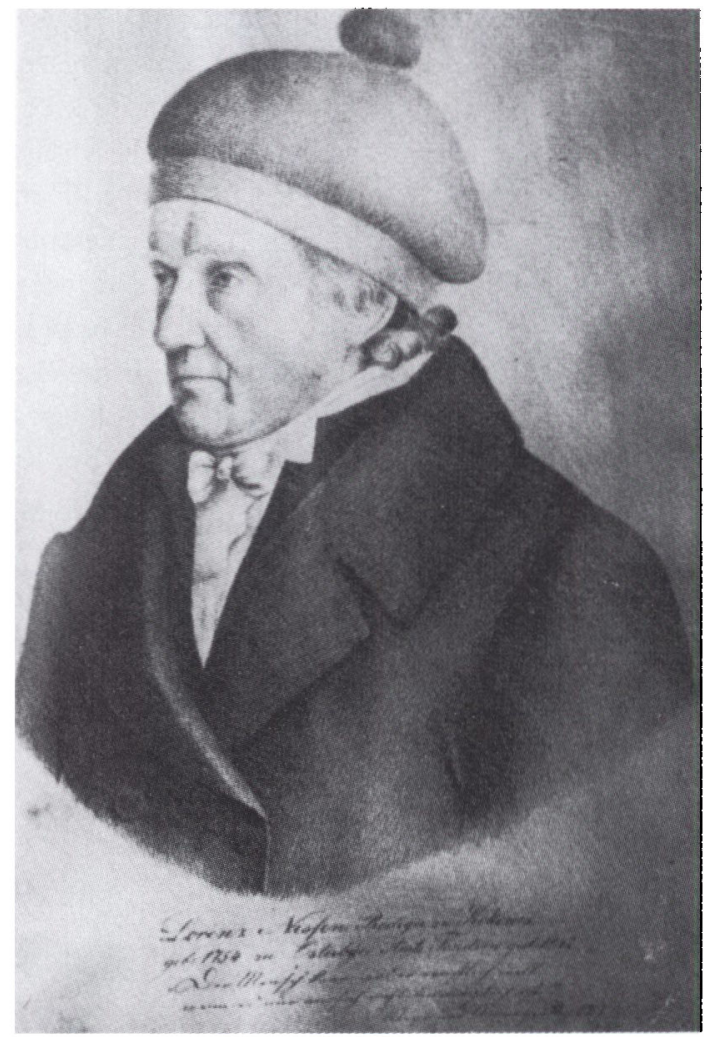

stillede måske ikke altid de helt store krav med hensyn til den danske prædikants danske sprogkundskaber, men der findes ikke et eneste eksempel på, at repræsentanterne for byens borgerskab, der valgte præsten ved Helligåndskirken, har givet afkald på prøveprædikenen på dansk.

Kandidaterne sad i præstestolen under prædikestolen og overværede deres medkandidaters prædikener. J.N. Reuter gik som den ældste først på prædikestolen og talte i tre kvartér. L. Nissen holdt en lige så lang prædiken. Derefter var det Th. H. Jensens tur. Nissens prædiken "var den bedste, både efter form og indhold; den var mønstergyldig, men passede vel nærmest til en lærd tilhørerkreds. Reuters var god uden dog at være noget fremragende, « dømmer Th. H. Jensen i sin dagbog og fortsætter: "Begge to var mig underlegne med hensyn til udtalen af det danske sprog, skønt vi alle tre kun stod til middel deri. $\iota^{5}$

Efter at kandidaterne havde stået på Helligåndskirkens gamle prædikestol 
og efter bedste evne havde talt Guds ord, begav de i alt 32 rådmænd og deputerede borgere sig til rådhuset, hvor valget skulle finde sted. Lorenz Nissen fik 27 stemmer. ${ }^{6}$ Resultatet var formentlig ikke uventet for magistraten, der $\mathbf{i}$ sommeren eller efteråret 1795 havde opfordret $L$. Nissen til at søge det ledige danske prædikantembede. Den nye præst blev kaldet den 21. marts 1796, og en halv måned senere (8. april) konfirmerede kongen kaldelsen. L. Nissen ordineredes i Tønder på Christi Himmelfartsdag (5. maj) 1796, og en måned senere, den 5. juni, tiltrådte han sit danske prædikantembede ved Flensborgs Helligåndskirke. Kun fem dage efter tiltrædelsen holdt han sin første ligtale på tysk i Mariekirken, idet præsten dér lige var død. L. Nissens person må have gjort et stort indtryk på flensborgerne. Kun få dage efter sin tale i den tyske sognekirke fik han nemlig besøg af en rådmand og to deputerede borgere, som på »nogle venners vegne« overbragte ham en gave på 777 daler. ${ }^{7}$ Pengene faldt et tørt sted.

Hvem var nu denne Lorenz Nissen, der så sent som i 41-års alderen tog teologisk embedseksamen og så hurtigt vandt flensborgernes gunst?

\section{En bondesøns vej til embede}

Lorenz Nissen var født i Østerby/Medelby sogn (Kar herred) den 1. februar 1754. Hans forældre var wuformuende, men agtværdige bønder« - som hans andre forfædre havde været det. Fra sit syvende til femtende år vogtede han kvæg og hjalp til ved arbejdet ude på marken. Skolen besøgte han kun om vinteren. Det var dog ikke degnen, men bønderkarle, der underviste ham i at læse, skrive og regne. De katekiserede endda; selv om det skete på deres egen måde og ikke efter de gængse metoder, var det ikke uden al nytte. I 15-års alderen forlod Lorenz Nissen sin hjemby. Han flyttede til degnen i Faretoft (Bøking herred), hos hvem han skulle være lærermedhjælper og samtidig forberedes til konfirmationen. "Efter Soholmbro var det slut med modersmålet, vort provinsialdansk; det frisiske lød som arabisk i mine øren, og plattysk forstod jeg kun lidt af«, fortæller han i sin selvbiografi. »Jeg var en dansk dreng blandt frisere. $\aleph^{8}$

Efter konfirmationen kom Lorenz Nissen til Lille Volstrup i Angel, hvor han fik ansættelse som »lejelærer ( (vikar eller anden lærer). Her følte han sig mere hjemme end i Frisland. En ukuelig læselyst kom over ham. Alle bøger, både gode og dårlige, der kunne støves op, blev læst. Denne trang til at skaffe sig kundskaber, forlod ham aldrig mere.

I Lille Solt, nabolandsbyen mod syd, mødte han en gruppe pietistiske familier. De kaldtes »de hellige«. Det var fromme folk, gode og retskafne 
kristenmennesker, der hurtigt vandt hans sympati. L. Nissen begyndte at læse Jac. Speners, A.H. Franckes og andre pietisters skrifter.

På mange søndage vandrede han til Flensborg - og ofte stod han i den danske kirke ved siden af alteret for at lytte til pastor Balthasar Holsts "noget sværmeriske prædiken«, som tiltrak ham. ${ }^{9}$ Han besøgte også de tyske gudstjenester i Marie- og Nikolaikirken.

L. Nissen blev i Lille Volstrup $\mathrm{i}$ tre år. Det var her, hans $\mathrm{i}$ begyndelsen famlende og tilfældige søgen efter kundskaber opstod. Den sønderjysktalende bondedreng fra Kær herred tilegnede sig sin nye viden på tysk, som var det fremherskende dannelsessprog.

Flere stillinger som huslærer og ved andre landsbyskoler fulgte efter. I Lyksborg arbejdede han hos tingskriveren, som degn og organist i Kosel kom han på kant med den "herskesyge« præst. Det var dårlige betingelser for hans private studier. Hans økonomiske forhold var ikke de bedste. Endelig, i 1779, blev han ved fortsat flid og energi skrive- og regnemester i Sønderborg. Og her kastede han sig med ynglingens iver over teologiske studier og begyndte at lære sprog. Han forbedrede sit tysk, lærte fransk, latin og græsk. ${ }^{10}$

Under opvæksten var $\mathrm{L}$. Nissen blevet oplært i den dengang gældene ortodokse troslære. Nu kom tvivlen over ham, og han blev overbevist om det rigtige i tidens alment udbredte fornuftsprægede teologi - oplysningstidens idealer. Med voksende skepsis så han på læren om den guddommelige supranaturalisme, d.v.s han mistede troen på en umiddelbar guddommelig åbenbaring som religionens kilde og på forestillingen om Guds indgriben i natursammenhængen ved undere. Mere og mere kom han til at afvise læren om, at arvesynden skulle have fordærvet menneskets moralske evne, således at menneskets fornuft ikke formåede at fatte den overnaturlige Gud og ikke kunne dømme i spørgsmål, der berørte menneskets frelse. Lorenz Nissen stolede på det gode i mennesket og på menneskets medfødte sunde fornuft. Han mente nu, at Biblens ord ikke kunne stå i modsætning til almene fornuftssandheder. Efter hans mening var det desuden en anmasselse, når de såkaldte rettroende hævdede at vare i besiddelse af den ene ufejlbarlige sandhed, der alene førte til menneskets frelse. Denne frelse kunne umuligt afhænge af, at alle mennesker havde den samme tolkning af Biblens ord. Biblen er Guds åbenbaring, men Biblens forfattere var mennesker, og alle mennesker kan fejle. Det gælder både profeterne $\mathrm{og}$ dem, der udlægger skriftens ord. Menneskene var og er forskellige, og dermed fandtes og findes der også forskellige tolkninger af Biblen. Efter L. Nissens mening førte de ortodokse lutheraneres holden fast ved en ordret og fornuftsstridig bibeltolkning til en blind og kraftles kulsviertro. For ham var kristendommens væsen kærlighed til Gud; afgørende var, at mennesket var af rent hjerte og førte et kristeligt liv i troen på den retfærdige 
og barmhjertige fader i himmelen. Han kaldte sin opfattelse "rationalistisk «," . Han hyldede en personlighedsreligion, der knyttede erkendelse og følelser, oplysningstidens optimistiske menneskesyn og pietisternes subjektivisme sammen til en harmonisk enhed. L. Nissen var langtfra stivnet i en gold rationalisme, den pietistiske påvirkning spores tydeligt. Rationalisten var åben for de mere følelsesbetonede strømninger i sin samtids åndsliv; han havde bevaret sin hjertevarme og sit åbne sind for naturen og livet omkring sig. Hans sympati for pietisterne og hans store begejstring for J.J. Rousseaus værker og hans moralsk begrundede skepsis over for Voltaire taler et tydeligt sprog. ${ }^{12} \mathrm{~L}$. Nissen, der på den ene side dyrkede den menneskelige fornuft, var på den anden side ikke bange for at "bandlyse fornuften fra troens område « ${ }^{13}$, men direkte fornuftsstridig måtte tolkningen af Biblens ord dog ikke være.

Lorenz Nissen fremhæver i sin selvbiograf, at hans flittige natlige studier ikke var rettet mod et bestemt mål, de tjente til at tilfredsstille hans store videlyst. Det var provst i Sønderborg G.J. Schmid(t) og den daværende cand. theol. og senere præst i Højer Chr. Petersen, der overtalte autodidakten til at tage teologisk embedseksamen. Efter en betænkningstid på omtrent tre måneder besluttede den 40 -årige skrive- og regnemester at vove springet. Han søgte dispensation fra det treårige universitetsstudium i maj 1794. Den blev bevilget tre måneder senere. $\mathrm{Og}$ han bestod en mundtlig prøve hos generalsuperintendent Adler. Dermed var vejen jævnet til - efter en lang omvej - at få ungdomsdrømmen ${ }^{14}$ opfyldt. I første halvdel af oktober 1795 underkastede han sig med heldigt resultat teologisk eksamen på Gottorp. Retten til at søge præsteembede var opnået.

Inden han selv rettede sit blik mod et bestemt embede, modtog han $\mathrm{i}$ november 1795 en indbydelse fra Flensborgs magistrat til at holde en gæsteprædiken i Helligåndskirken. "Jeg havde aldrig tænkt mig at blive dansk præst. Mit modersmål var ganske vist vort provinsialdansk [d.v.s. Kær herreds sønderjyske dialekt], men efter at jeg som dreng havde forladt vor landsby, havde jeg ikke befattet mig mere med det danske sprog og kun en sjælden gang læst en dansk bog, og af den grund kunne jeg ikke være øvet i dette sprog. ${ }^{15}$ Hans gode ven og velynder provst Schmid overbeviste ham om, at sproget ikke kunne være nogen hindring og overtalte ham til at følge indbydelsen.

\section{Den danske præsts vilkår}

Mens den højtyske prædiken holdt sit indtog i Flensborgs tyske kirker omtrent 100 år efter reformationen, talte de danske prædikanter ved Helligåndskirken formentlig dialekt eller et stærkt dialektpræget rigsmål til langt op i 1800-tallet. 
Provst Schmid havde ret, da han mente, at den nybagte teologs sønderjyske "bondesprog " ikke stod $\mathrm{i}$ vejen for en ansættelse som dansk prædikant $\mathrm{i}$ Flensborg og som det skulle vise sig, var medkandidaternes dansk ikke bedre.

Lorenz Nissen tiltrådte sit embede den 5. juni 1796. Et stort arbejde ventede ham - i de tyske kirker, idet der ved både Marie- og Nikolaikirken døde en præst samme år. L. Nissen vikarierede ved begge kirker. Ofte holdt han først en tysk prædiken $i$ en af byens store sognekirker og umiddelbart derefter en dansk prædiken i den lille Helligåndskirke. Stolt beretter han, at de tyske kirker var stuvende fulde, når han prædikede. Det menneskefyldte kirkerum vakte hans begejstring. Han følte en voksende glæde stige op i sig over kaldet at forkynde den sandhed, der fyldte hans hjerte. Før det første år var gået, segte han det ledige præstekald ved Mariekirken, men uden held. At være tysk præst var tydeligvis det mest attraktive.

Hans beretning om det danske kirkearbejde er fåmælt og ikke særlig opløftende. L. Nissen blev hurtigt klar over, at han ikke ville ende sine dage som dansk præst i Flensborg. Han savnede en sognemenighed, der var hans. De danske gudstjenester besøgtes af tyende, småkårsfolk og sømænd samt beboerne af Hulvejene, af byens østlige yderdistrikt, et udpræget småkårskvarter. Han måtte gå mange og lange veje ud over hele byen, når han besøgte sine "menigheds«børn. Menigheden bestod af fattigfolk, der ud over skrifteofferet ikke gav indtægter. L. Nissen klagede ikke over manglende indkomst, men hans indtægter stammede fra frivillige gaver og var dermed usikre og afhængige af de rige købmænds velvilje. Han ville imidlertid ikke bygge sin fremtid på usikkerhed og gavmildhed.

I sin resolution af 14 . oktober 1782 havde Christian 7. bestemt, at de danske prædikanter skulle fritages for at holde tyske vesperprædikener i sognekirkerne. Prædikanten skulle i fremtiden kun assistere de tyske sognepræster i nødstilfælde og kun på de tyske præsters forlangende. Hensigten med denne bestemmelse var, at den danske prædikants hidtidige danske og tyske embeder og hans to embedssprog skulle skilles og det tyske embede reduceres til et minimum. Det blev derved understreget, at den danske prædikants virkested var Helligåndskirken og hans virkekreds »danskerne«, nemlig de danskere, der boede i byen eller midlertidigt opholdt sig i Flensborg. Kun de rent dansksprogede familier havde - efter reskriptets hensigt - lov til at holde sig til den danske prædikant. Hans hidtidige tysktalende kirkegængere og de dobbeltsprogede familier blev tvunget til at søge til de tyske præster. Resolutionen begrænsede de danske prædikanters opgaver til et rent dansksproget arbejde for at forhindre, at prædikanterne fortsat hvervede tilhængere blandt det bedre, tysktalende borgerskab. I mere end hundrede år havde danske prædikanter nemlig arbejdet 


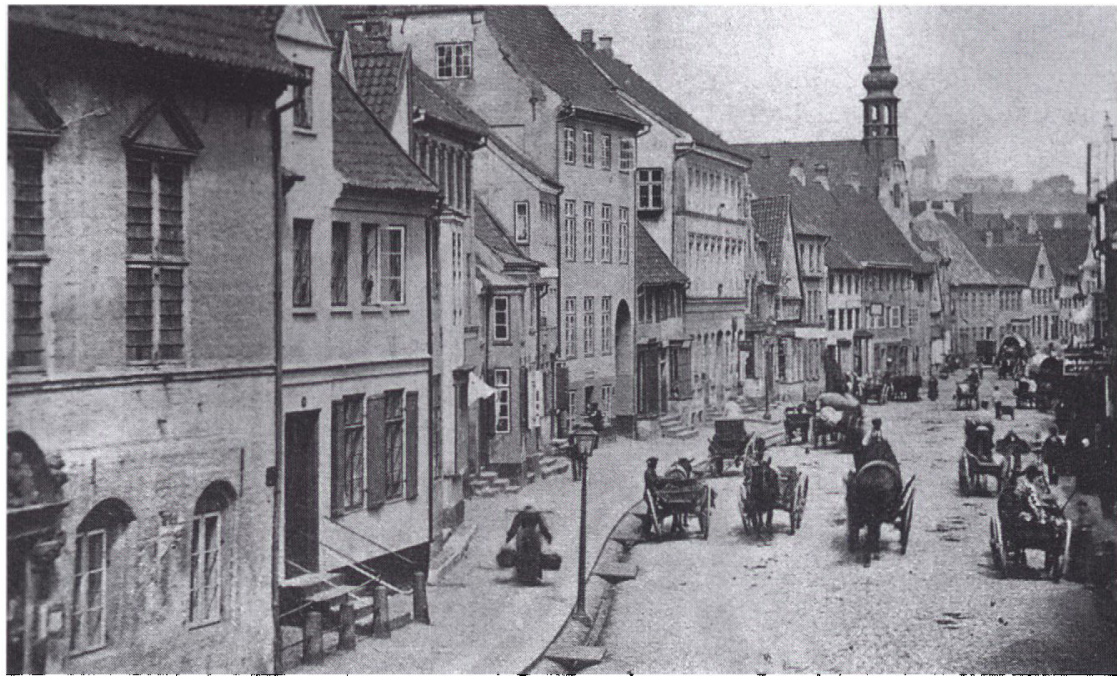

Det gamle Flensborg var en travl by. Billedet viser Storegade for 1880 set fra det middelalderlige rådhus t.v. mod Helligåndskirken $i$ baggrunden. Husene var dengang mindre end $i$ dag, og derfor virker den lille Helligåndskirke egentlig ret stor. Lag marke til de mange hestekoretojer og konen med bareåg. Omtrent sådan må byen have set ud på Lorenz Nissens tid. Foto i Dansk Centralbibliotek for Sydslesvig.

på, at deres præstekald blev udvidet til et tysk-dansk dobbeltembede. $O g$ enkelte af de mest begavede danske prædikanter havde gjort store indhug $i$ de tyske præsters indtægter. Resolutionen var afslutningen på en række langvarige processer, som de tyske gejstlige havde ført mod flere danske prædikanter, der havde krænket de tyske sognepræsters rettigheder. Reskriptet var en sen sejr til Marie- og Nikolaikirkens præster. Men der kan næppe tales om et nederlag for det danske $i$ byen. De fleste danske prædikanter havde $i$ deres stræben efter et tysk-dansk kald mere eller mindre forsømt deres danske embedspligter, flere af dem var endda begyndt at prædike på tysk i den danske kirke. Den i oktober 1782 forordnede strenge adskillelse mellem embederne og sprogene bekræftede Helligåndskirkens status som »den danske kirke« i Flensborg og slog fast, at Helligåndskirkens prædikant var byens »danske præst «! Væsentligt for fremtiden var nu spørgsmålet, om reskriptets bestemmelser blev overholdt konsekvent.

Den danske menighed var 15 år efter Christian 7.s resolution reduceret til en ren fattigfolksmenighed. Bestemmelsen om, at den danske prædikant skulle assistere de tyske sognepræster i nødstilfalde, udnyttedes kraftigt - og til stor glæde for L. Nissen. Der findes dog ikke nogen klager over ham. Det kan kun betyde, at han ikke blandede sine to embeder, d.v.s. at han ikke prædikede 
tysk i Helligåndskirken, og at han ikke prøvede at trække tyske menighedsbørn over i de danske kirkegængeres rækker. Det var han sikkert for redelig til. Og han følte sig formentlig for lidt som dansk præst. Hans selvbiografi afslører, at det var de tyske prædikener, der gav ham den store indre lykke. Og det var de fine tyske kirkegængere, der beundrede ham.

Lorenz Nissen var en fremragende tysk og en (middelmådig eller mere sandsynligt) rimelig god dansk prædikant. Pastor L.M. Wedel, der på sine indenlandske rejser besøgte Flensborg flere gange, hørte Nissen prædike på tysk og på dansk. Om den tyske prædiken skriver han: "Der var alt, synes mig, hvad der udfordres til en åndelig tale: sprog, stemme, mine, anstand og afhandling; alt var såre godt, kristeligt, fornuftigt, overbevisende, rørende og behageligt. Jeg har ingensinde hørt en bedre tysk prædiken, og det samme siger også de fleste indbyggere selv, de ærer, elsker og agter denne brave præst, og frygter kun for, at han skal blive befordret bort fra dem. Han er et sjaldent eksempel, da hans flid og store naturgaver er forenede med sand menneskekærlighed, så at alle taler vel om ham.» Nissens danske prædiken gjorde langtfra så stort et indtryk på L.M. Wedel. Det danske sprogs »vendinger og karakteristika har han ikke så meget i sin magt som det tyske; imidlertid var jeg såre tilfreds med talen i det hele. $\kappa^{16}$ Embedsbroderens dom skal ikke betvivles, men der kan dog siges en del imod den. I en samtidig bog om den danske kirkeforfatning fremhæver værkets forfatter, at det er "meget vigtigt for gudstjenesten og religionshandlinger, at sproget, som derved bruges, er det allerforståeligste, om det end derved just ikke altid kan være tillige det allersirligste; og følgelig bør gejstligheden på hvert sted unægtelig være vel bekendt med almuens sprog; thi denne fatter derved tillige en større fortrolighed både til personen og sagen. ${ }^{17}$ Det var vel netop dette krav L. Nissen efterkom, når han prædikede på dansk i Helligåndskirken. Han holdt såvidt vi kan skønne sin gudstjeneste på sit sønderjyske almuemål. Han talte sandsynligvis i enkle vendinger til simple folk. Stilistiske sirligheder og åndrig "afhandling « ville have været forkert anbragt. Prædikanten var jo en gammel, jordnær pædagog. Hans danske sprogkundskaber kan ikke have været så ringe, som Wedel giver indtryk af. I februar 1801 blev L. Nissen nemlig sognepræst på Kegnæs/Als i området med dansk kirkesprog, hvor han virkede til sin død den 27. februar 1842 uden at gøre sine sognebørn »kirchenscheu«. ${ }^{18}$ Han havde altså selv tillid til sine danske sprogkundskaber, da han søgte embedet, og han klarede opgaven.

Sprogproblemet bør imidlertid også betragtes fra en anden synsvinkel. Efter næsten 30-års virksomhed som dansk præst nedskrev Lorenz Nissen sine erindringer - på tysk. Det er ikke uinteressant: Nissens barndomssprog var 
sønderjysk, hans prædikesprog sønderjysk/dansk, men hans dannelses- og skriftsprog var tysk. Det er en symptomatisk sprogsituation for området nord for Slien: så godt som alle, der forlod det landlige barndomsmiljø for at gå den akademiske vej, skiftede fra sønderjysk/dansk til tysk. I løbet af 1800tallet fik dette sprogskifte en afgørende betydning for den politiske udvikling i hertugdømmet Slesvig.

Tilbage til tiden i Flensborg.

Den tyske gudstjeneste affødte både indre tilfredsstillelse og en strålende ydre tilslutning. Den danske "menighed «, denne tilfaldige gruppe af spredtboende, fattige og simple kirkegængere, medførte derimod kun besværligheder. ${ }^{19}$ Efter Wedels indtryk at dømme, besøgtes de danske gudstjenester af få danske flensborgere, af rejsende, købmænd, skippere, prangere, kniplingskræmmere og andre fremmede fra de danske egne. I modsætning til den store, høje og med kostbare malerier udsmykkede Mariekirke var Helligåndskirken «simpel», "uden noget sirligt», den manglede et orgel, og der blev ikke ringet med klokkerne.$^{20}$ Kirkebygningens usselhed svarede til menighedens.

Uden tvivl var de danske kirkegængeres sociale status blevet meget ringere, efter at resolutionen af 14 . oktober 1782 havde indsnævret den danske prædikants virkekreds til »danskerne«. Antallet af deltagere i gudstjenesten i Helligåndskirken var gået tilbage. Blandt andet vel også, fordi kirkeligheden altid har været mindre hos de fattige end hos borgerskabet. I 1781 gik 1.609 personer til alters i Helligåndskirken, i 1799 var tallet dalet til omkring $1.000{ }^{21}$ Selv om mange købmand besøgte Flensborg, byen var jo leverandør til store dele af Jylland, i alt fald hele Nordslesvig, er dette tal dog stadig alt for stort til at kunne bekræfte Wedels tilfældige indtryk af, at det overvejende var fremmede eller rejsende, der besøgte de danske gudstjenester. Og når man sammenligner de to nævnte tal, bør man tage hensyn til nyordningen fra 1798 , der automatisk medførte et mindre antal altergæster. I dette år faldt det private skriftemål bort, hvorved Helligåndskirkens skriftestol blev overflødig, og det bestemtes, at nadveren kun skulde holdes hver 12. søndag. Der må altså stadig have været et stort antal flensborgere, der holdt sig til den danske præst.

Lorenz Nissen, der selv kom fra små kår og forstod de ringere stilledes problemer og talte deres sprog, kunne have været en forstående og hjælpende sjælesørger netop for Helligåndskirkens fattigfolksmenighed. Men han søgte et andet, mere tilfredsstillende arbejdsfelt. L. Nissen forlod Flensborg allerede i foråret 1801 for at blive præst på Kegnes. Den danske menigheds manglende status som sognemenighed, den danske prædikants usikre økonomiske situation og prædikantens underordnede rang som tysk hjælpepræst, som især for en ældre prædikant kunne være en ubehagelig byrde, var de for L. Nissen afgørende motiver, da han søgte væk fra Helligåndskirken. 
"Skønt indeknebet $\mathrm{i}$ den mørke Helligåndsgang havde jeg sammen med mine kære tilbragt fem lykkelige og glade år af mit liv i Flensborg «, "taknemmelige, rørte og med våde blikke så vi den kære by i dalen forsvinde«, skrev han et kvart århundrede senere i sin selvbiografi. ${ }^{22}$

\section{NOTER OG HENVISNINGER}

1. Otto Fr. Arends: Gejstligheden i Slesvig og Holsten. Fra Reformationen til 1864. Bd 1-3, Kabenhavn 1932. Bd 2, s. 195: Johann Nicol. Reuter (1761-1829) blev præst i Horsbøl (Viding herred) 1796 og var derefter præst i Havetoft (Strukstrup herred) 1811-1829.

2. O.Fr. Arends: Gejstligheden, bd. 1, s. 398: Thomas Hoyer Jensen (1771-1846). Præst v. Helligåndskirken 1801, i Bov 1820-43.

3. Lorenz Nissen: Meine Wege und Umwege zur Kirche. Eine autobiographische Erzählung. Altona 1826 (Reprint: Schleswig 1982), s. $113 \mathrm{ff}$ - Se ogsả Th. Hoyer Jensens dagbog: H.F. Petersen: Helligåndskirken i Flensborg. i: Slesvigske Kvinders Julebog, s. 7-24. København 1946.

4. Ábenrås Bys Historie, Red. af Johan Hvidtfeldt og Peter Kr. Iversen. Bind II, 1721-1864. Skrifter udgivne af Historisk Samfund for Sønderjylland, nr. 25 (1967). S. 59.

5. H.F. Petersen: Helligåndskirken, s. 12.

6. L. Nissen: Wege und Umwege, s. 114.

7. L. Nissen: Wege und Umwege, s. 117.

8. L. Nissen: Wege und Umwege, s. 1ff.

9. L. Nissen: Wege und Umwege, s. 25.

10. L. Nissen: Wege und Umwege, s. 67ff.

11. L. Nissen: Wege und Umwege, s. 76ff.

12. L. Nissen: Wege und Umwege, s. 86 .

13. L. Nissen: Wege und Umwege, s. 19.

14. L. Nissen: Wege und Umwege, s. 16ff.

15. L. Nissen: Wege und Umwege, s. 113.

16. L(ago) M(athias) Wedel: Indenlandske Rejse igjennem de betydeligste og skjønneste Egne af de danske Provindser. Bd 1, Kjøbenhavn 1803. S. 91, 94.

17. Henrich Ussing: Kirkeforfatning i de kongelige danske Stater samt dens vigtigste Fordele og Mangler samt muelige Forbedringer. 4. del 1. bd. Sorø 1788. S. 211.

18. Dansk præste- og sognehistorie. Bd X Haderslev stift. Ugivet af A. Pontoppidan Thyssen. Árhus 1985. S. 676f.

19. Se derimod Poul Erichsen: Om end Taarnene falde. København 1921. P. Erichsen skriver på s. 50: "Som prast ved Helligåndskirken synes han (L. Nissen) at have varet almindelig afholdt og elsket" .. "Selv følte han sig lykkelig og tilfredsstillet ved at være præst for de danske i Flensborg."

20. L.M. Wedel: Indenlandske rejse, s. 91, 94.

21. Peter Rivesell: Versuch einer Beschreibung der Stadt Flensburg. Altona 1817. S. 592.

22. L. Nissen: Wege und Umwege, s. $122 f$. 
